\title{
Carbon Nanotubes: Mechanism, Langmuir Hinshelwood Growth Kinetics and It Application for the Removal of Chromium (VI)
}

\author{
Ahmed $\mathrm{A}^{1^{*}}$, Abdulhakim SA ${ }^{2}$, Ishaq $\mathrm{K}^{3}$, Saka $\mathrm{AA}^{3}$, Peter $\mathrm{MS}^{1}$ and Chidinma OU ${ }^{1}$ \\ ${ }^{1}$ Department of Chemical Sciences, Federal University Wukari, P.M.B. 1020, Wukari, Taraba State, Nigeria \\ ${ }^{2}$ Department of Mathematic and Statistics, Federal University Wukari, P.M.B. 1020, Wukari, Taraba State, Nigeria \\ ${ }^{3}$ Chemical Engineering Department, Federal University of Technology Minna, P.M.B. 65, Minna, Niger State, Nigeria
}

*Corresponding author: Ahmed A, Department of Chemical Sciences, Federal University Wukari, P.M.B. 1020, Taraba State, Nigeria, Tel: +2348033576652; E-mail: ahmedio4ac@yahoo.com/aliyuahmed@fuwukari.edu.ng

Received date: August 9, 2017; Accepted date: August 18, 2017; Published date: August 24, 2017

Copyright: (c) 2017 Ahmed A, et al. This is an open-access article distributed under the terms of the Creative Commons Attribution License, which permits unrestricted use, distribution, and reproduction in any medium, provided the original author and source are credited.

\begin{abstract}
In this study, kinetic model for decomposition of acetylene for the production of carbon nanotubes (CNTs) have been explored. The kinetics model described the CNTs growth in the chemical vapour deposition (CVD) reactor while Arrhenius equation was employed for the determination of the activation energy. The result of the analysis shows activation energy of $237.2483 \mathrm{kJmol}^{-1}$ which is an indication that the reaction that leads to the production of CNTs is adsorption inclined. The observed frequency factor shows that the reactants' particles collide at faster rate which enhances CNTs growth. The prepared CNTs were characterized using high resolution scanning electron microscope/high resolution transmission electron microscope (HRSEM/HRTEM), selected area electron diffraction (SAED), energy dispersive spectroscope (EDS) and Brunauer Emmett Teller (BET) method for morphology, crystallinity, elemental composition and surface area. CNT with best physiochemical properties was used to investigate effect of CNTs dosage, $\mathrm{pH}$, contact time and temperature on percentage removal of chromium (VI). The pseudo first and second order rate equations were tested on kinetic data and the pseudo fist order rate kinetics best described the adsorption process. The equilibrium data shows satisfactorily fitted the Langmuir isotherm $\left(R^{2}=0.9914\right)$ than the Freundlich isotherms $\left(R^{2}=0.09758\right)$, Dubinin- Radushkevich isotherms $\left(R^{2}=0.9092\right)$ and Temkin isotherm $\left(R^{2}=0.9355\right)$.
\end{abstract}

Keywords Carbon Nanotubes; Chemical Vapour Deposition; Langmuir Hinshelwood Kinetic Model; Adsorption Study

\section{Introduction}

Heavy metal pollution has been the main concern of many researchers for many years because of their toxicity towards the quality of life and the environment as whole [1-4]. Research have shown that continuous exposure to low levels of heavy metals may resulted in bioaccumulation and resulting health consequences in humans [5]. Chromium is one of the most poisonous heavy metal ions which are discharge with effluents of industries such as metallurgical, electroplating, leather tanning and others [6]. Accumulation of this metal in the human body can lead to some diseases such as cancer in the lung, allergic skin irritations, epigastria pains, vomiting and nausea [7]. Chromium can occur in an oxidation state of trivalent or hexavalent depending on it source. But research has shown that chromium (VI) is far more toxic than chromium (III) [8]. Amongst the methods available for removing chromium pollutant from aqueous effluent includes; electrochemical treatment, chemical precipitation, reverse osmosis, membrane technologies, adsorption process on adsorbent and various biological processes [9-11].

Most of these methods are not widely acceptable because of their inapplicability to a wide range of pollutants, high cost of operation and low efficiency [12]. The adsorption process is arguably one of the promising methods for the removal of heavy metal ions because of it flexibility, reliability, low cost of operation and having the capacity to regenerate the exhausted adsorbent. Ever since the discovery of carbon nanotubes (CNTs) in the early 1991 by Iijima, it applications in the removal of pollutants have attracted substantial interest in the scientific community due to its extraordinary structures in terms of large diameter and length/diameter ratio, unique electrical and thermal properties as well as mechanical strength in the field of material science engineering [13].

Although, several methods such as arc discharge [14], flame or laser ablation [15,16], and chemical vapour deposition (CVD) [17-21], have been reported for the synthesis of CNTs. The CVD method is considered one of the most dominant, ideal, cost effective, versatile, transferable method of producing high quality and large quantity CNTs at relatively low synthesis temperature [22]. This method gives the opportunity of modifying multi-structural parameters such as diameter, length and alignment in order to obtain a well-defined and organized array of CNTs with different morphology for a specific area of application [23]. However, the understanding of the growth kinetics of CNTs is the key to develop its prospective applications [24,25]. Therefore, information on the kinetic study of CNTs in the CVD reactor is the subjects of this study.

The information about the kinetic study of CNTs can be deduced by observing the variation in mechanism of the decomposition of hydrocarbon over time. Losurdo et al. [26] explored low pressure CVD kinetics in a real-time monitoring by using methane $\left(\mathrm{CH}_{4}\right)$ and hydrogen has $\left(\mathrm{H}_{2}\right)$ as carbon sources on two polycrystalline metal substrates of copper $(\mathrm{Cu})$ and nickel $(\mathrm{Ni})$ catalysts at a reaction temperature of $900^{\circ} \mathrm{C}$, with the aim of investigating the role of $\mathrm{H}_{2}$ in distinguishing CNTs kinetics growth. From their findings, it was reported that $\mathrm{H}_{2}$ slows down the deposition kinetics of CNTs on $\mathrm{Cu}$ by 
Citation: Ahmed A, Abdulhakim SA, Ishaq K, Saka AA, Peter MS, Chidinma OU (2017) Carbon Nanotubes: Mechanism, Langmuir Hinshelwood Growth Kinetics and It Application for the Removal of Chromium (VI). J Membr Sci Technol 7: 174. doi:10.4172/2155-9589.1000174

Page 2 of 10

blocking the active sites on the $\mathrm{Cu}$ surface, which resulted in poor quality morphology of the CNTs grown. On the other hand, Bi et al. $[26,27]$ reported the direct synthesis of CNTs on dielectric substrates by ambient pressure CVD at a temperature range between 1100 to $1200^{\circ} \mathrm{C}$ using a gas mixture of $\mathrm{CH}_{4}, \mathrm{H}_{2}$ and $\mathrm{Ar}$ as the carrier gas. Their finding revealed the possibility of the formation of CNTs at a high temperature of about $1200^{\circ} \mathrm{C}$ over $\mathrm{Si}, \mathrm{SiO}_{2}$ and $\mathrm{Al}_{2} \mathrm{O}_{3}$ substrates.

In this study, high quality CNTs growth using CVD method and the growth kinetics and mechanism of formation is reported. Fe-Ni catalyst over a kaolin substrate using wet impregnation method was used for the deposition of acetylene $\left(\mathrm{C}_{2} \mathrm{H}_{2}\right)$ carbon source using $\mathrm{Ar}$ as a carrier gas. Also, the activation energy and the frequency factor of the $\mathrm{C}_{2} \mathrm{H}_{2}$ decomposition were reported using measured gas phase concentrations in the CVD reactor while the structural morphology of the prepared CNTs were studied using high resolution scanning electron microscope (HRSEM), selected area electron diffraction (SAED), high resolution transmission electron microscope (HRTEM), energy dispersive spectroscope (EDS) and Brunauer Emmett Teller (BET) surface area analyzer. Also, the CNTs with best structural morphological property were used study the effect of dosage, contact time, $\mathrm{pH}$ and temperature on the percentage removal of chromium (VI). Furthermore, the kinetic and adsorption isotherms were explored to establish the best fitted model with the adsorption study.

\section{Materials and Methods}

\section{Materials}

The acetylene and Argon gases were sourced from BOC Nigeria and they were of analytical grade with percentage purity of $99.99 \%$. Chemicals used in this study include anhydrous potassium dichromate (VI), sodium hydroxide $(\mathrm{OH})$, and hydrochloric acid $(\mathrm{HCl})$ which were obtained from Sigma Aldrich and they were all of analytical grade with percentage purity in the range of $98-99.99 \%$.

\section{Methods}

Production of MWCNTs: The catalyst used, which was thoroughly characterized in earlier studies, had a BET surface area of $3.76 \mathrm{~m}^{2} / \mathrm{g}$, pore volume of $1.9 \times 10^{-3} \mathrm{~cm}^{3} / \mathrm{g}$ and pore size of $0.5986 \mathrm{~nm}$. The HRTEM of the catalyst also show lattice fringes of $0.3 \mathrm{~nm}$ with estimated catalyst particle size of 29-31 nm.

The experimental set-up consists of quartz boat $(11 \mathrm{~cm} \times 2.6 \mathrm{~cm})$ containing $0.5 \mathrm{~g}$ of catalyst, placed at the center of the glass quartz tube as shown in Figure 1. The furnace around the glass quartz tube was heated at $10^{\circ} \mathrm{C} / \mathrm{min}$ while argon (Ar) was flowing over the system at 30 $\mathrm{mL} / \mathrm{min}$ to create an inert environment before the reaction time. After the purging of the system from room temperature to $700^{\circ} \mathrm{C}$, the $\mathrm{Ar}$ flow rate was adjusted to $230 \mathrm{~mL} / \mathrm{min}$ and $\mathrm{C}_{2} \mathrm{H}_{2}$ was then introduced at flow rate of $150 \mathrm{~mL} / \mathrm{min}$ for reaction period of 45 minutes. A sampling probe was used to collect sampling gas which was directly introduced to gas chromatograph (GC) for chemical analysis. The growth experiment was stopped after 45 minutes reaction time by switching off the $\mathrm{C}_{2} \mathrm{H}_{2}$ gas, while the furnace was allowed to cool down to room temperature under a continuous flow of argon at a flow rate of $30 \mathrm{~mL} / \mathrm{min}$. The quartz tube was disconnected from the setup and the quartz boat was removed and the CNTs deposit was characterized using high resolution scanning electron microscope (HRSEM), selected area electron diffraction (SAED), high resolution transmission electron microscope (HRTEM), energy dispersive spectroscope (EDS) and Brunauer Emmett Teller (BET) surface area analyzer.

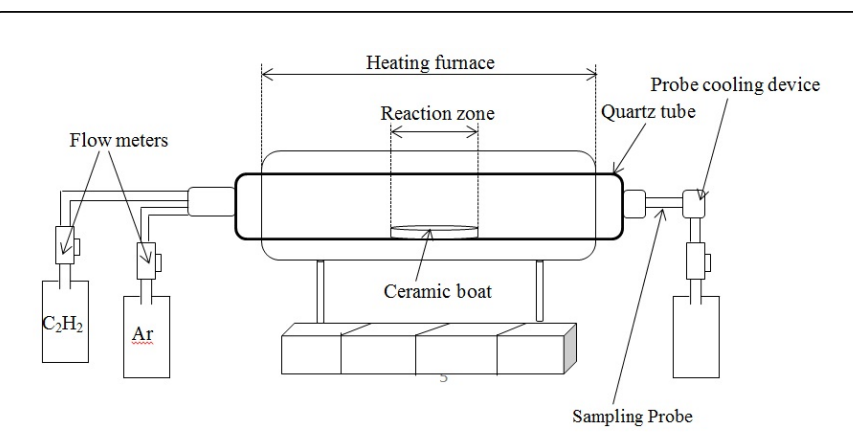

Figure 1: Schematic diagram of the CVD and experimental set-up.

Adsorption studies of chromium (VI) ion onto CNTs with best properties: The chromium (VI) adsorption experiments from its aqueous solutions on the prepared CNTs with best morphological properties were carried out using standard $10 \mathrm{mg} / \mathrm{L}, 50 \mathrm{mg} / \mathrm{L}$ and 100 $\mathrm{mg} / \mathrm{L} \mathrm{Cr}$ (VI) ion solution. The adsorption experiments were carried out by adding 0.2 to $1.0 \mathrm{~g}$ of the prepared CNTs adsorbents at an interval of 0.2 in $100 \mathrm{~mL}$ of the Cr (VI) ion solution. The optimal adsorption parameters are determined as a function of adsorbent dosage, $\mathrm{pH}$, contact time and temperature in the batch removal process. The solution were kept in a water bath shaker at $200 \mathrm{rpm}$ for a predetermined period of time, then after the solution was filtered using filter paper and $\mathrm{Cr}$ (VI) ion concentration in the filtrate was determined by an Atomic adsorption Spectrometer (PerkinElmer Analyst 400, Perkin-Elmer). The adsorption capacity and the percentage removal of $\mathrm{Cr}(\mathrm{VI})$ ion were calculated using Equation (1) and (2) respectively.

$$
q_{e}=\frac{\left(C_{o}-C_{e}\right) V}{m}
$$

$$
\text { Percentage Removal }=\frac{\left(C_{o}-C_{e}\right)}{C_{o}} \times 100
$$

Where $\mathrm{q}_{\mathrm{e}}$ is the equilibrium adsorption capacity of the adsorbent ( $\mathrm{mg} / \mathrm{g}), \mathrm{C}_{\mathrm{o}}$ and $\mathrm{C}_{\mathrm{e}}$ is the initial and equilibrium concentration of $\mathrm{Cr}$ (VI) ion in solution $(\mathrm{mg} / \mathrm{L})$ respectively, $\mathrm{m}$ is the weight of the adsorbent $(\mathrm{g})$ and $\mathrm{V}$ is the volume of the solution used $(\mathrm{L})$.

Effect of CNTs Dosage on the percentage removal of chromium (VI) ion: The effect of adsorbent dosage on the adsorption of $\mathrm{Cr}$ (VI) ion solution with initial concentration of $10 \mathrm{mg} / \mathrm{L}, 50 \mathrm{mg} / \mathrm{L}$ and $100 \mathrm{mg} / \mathrm{L}$ prepared by different dilution of the stock solution $(1000 \mathrm{mg} / \mathrm{L})$. The solutions were contacted with different CNTs adsorbent dosage of 0.2 , $0.4,0.6,0.8$ and $1.0 \mathrm{~g}$ and sharked at $200 \mathrm{rpm}$ at $30^{\circ} \mathrm{C}$. The adsorbent was then filtered and the filtrate was then analyzed using the AAS. The optimum dosage is obtained where the percentage removal of the $\mathrm{Cr}$ (VI) ion is maximum from the experiments.

Effect of $p H$ on the percentage removal of chromium (VI) ion: The effect of $\mathrm{pH}$ on the adsorption was studied by varying $\mathrm{pH}$ in a range of $2,4,6,8,10$ and 12 at optimum CNTs do, contact speed of $200 \mathrm{rpm}$ and room temperature. The $\mathrm{pH}$ of the solutions was adjusted sage in above section by drops of $0.5 \mathrm{~mol} / \mathrm{dm}^{3} \mathrm{NaOH}$ or $0.5 \mathrm{~mol} / \mathrm{dm}^{3} \mathrm{HCl}$ solutions. The $\mathrm{pH}$ meter was standardized with buffer solution before every measurement during the experiments. 
Effect of contact time on the percentage removal of chromium (VI) ion: The effect of contact time on the adsorption was studied at an interval of 30, 45, 60, 75 and 90 minutess of $\mathrm{Cr}(\mathrm{VI})$ ion solution of initial concentration of $10 \mathrm{mg} / \mathrm{L}, 50 \mathrm{mg} / \mathrm{L}$ and $100 \mathrm{mg} / \mathrm{L}$ containing optimum CNTs dosage at room temperature and stirring speed of 200 rpm.

Effect of temperature on the percentage removal of chromium (VI) ion: The effect of temperature on the adsorption was studied at different temperatures of $30^{\circ} \mathrm{C}, 40^{\circ} \mathrm{C}, 50^{\circ} \mathrm{C}, 60^{\circ} \mathrm{C}$ and $70^{\circ} \mathrm{C}$ by taking optimum CNTs dosage at stirring speed of $200 \mathrm{rpm}$.

\section{Results and Discussion}

\section{Kinetic studies}

The kinetic of CNTs synthesis is hypothesized to be as follow. First is the decomposition of $\mathrm{C}_{2} \mathrm{H}_{2}$ to form free radicals in an inert environment on $\mathrm{Fe}-\mathrm{Ni} / \mathrm{kaolin}$ catalyst surface using argon as a carrier gas. Once the catalyst was exhausted, the CNTs formation occurred in the gas phase. As the residence time increases, the concentration of the active species changed, leading to a variability of the thickness of the CNTs. In this study, a simple growth kinetics model is applied to describe the observed CNTs growth as presented in the following proposed reactions mechanism.

$$
\begin{aligned}
& \text { Adsorption: } \mathrm{C}_{2} \mathrm{H}_{2}(\mathrm{~g})+\mathrm{X} \rightarrow \mathrm{C}_{2} \mathrm{H}_{2} . \mathrm{X} \ldots \ldots \text { (3) } \\
& \text { Surface reaction: } \mathrm{C}_{2} \mathrm{H}_{2} . \mathrm{X} \rightarrow 2 \mathrm{CNTs} . \mathrm{X}+2 \mathrm{H} . \mathrm{X} \ldots \ldots \text { (4) } \\
& \text { Desorption: CNTs. } \mathrm{X} \rightarrow \mathrm{CNTs}+\mathrm{X} \ldots \ldots \text { (5) } \\
& \text { Desorption: } 2 \mathrm{H} . \mathrm{X} \rightarrow \mathrm{H}_{2}+2 \mathrm{X} \ldots \ldots \text { (6) }
\end{aligned}
$$

Equations (3) and (4) showed the adsorption and the surface reaction step respectively. While Equations (5) and (6) above, represented the CNTs growth with evolution of hydrogen gas. Assuming Langmuir Hinshelwood Equation [28], the kinetic expression for the rate of acetylene consumed denoted by " $\mathrm{rC}_{2} \mathrm{H}_{2}$ ", from the proposed reaction mechanism can be written as;

$$
\mathrm{r}_{\mathrm{C} 2 \mathrm{H} 2}=\frac{\mathrm{k}_{\text {reaction }}{ }^{\mathrm{P}} \mathrm{C} 2 \mathrm{H} 2{ }_{\mathrm{H} 2}}{\left[1+\mathrm{k}_{\mathrm{C} 2 \mathrm{H} 2} \mathrm{P}_{\mathrm{C} 2 \mathrm{H} 2}+\left(\mathrm{k}_{\mathrm{H} 2} \mathrm{P}_{\mathrm{H} 2}\right)^{\frac{1}{2}}\right]^{3}}
$$

Where $\mathrm{k}_{\text {reaction }}$ is the kinetic parameter represents the constant of reaction rate, $\mathrm{PC} 2 \mathrm{H} 2$ and $\mathrm{PH} 2$ are the partial pressures of the acetylene and hydrogen respectively. Presented in Table 1 were the experimental data's used in the determination of kinetic parameters $\left(\mathrm{k}_{\text {reaction }}, \mathrm{k}_{\mathrm{C}} 2_{\mathrm{H}} 2\right.$ and $\mathrm{kH}_{2}$ ) using Equation (7) which can be linearized into Equation (8) for easy solving using POLYMATH 5.1 software

$$
\mathrm{Rk}_{1}-\mathrm{P}_{\mathrm{C} 2 \mathrm{H} 2} \mathrm{k}_{2}-\left(\mathrm{P}_{\mathrm{H} 2}\right)^{\frac{1}{2}} \mathrm{k}_{3}=1
$$

Were,

$$
R=\frac{1+\mathrm{k}_{\mathrm{C} 2 \mathrm{H} 2} \mathrm{P}_{\mathrm{C} 2 \mathrm{H} 2}+\left(\mathrm{k}_{\mathrm{H} 2}{ }_{\mathrm{P} 2}\right)^{\frac{1}{2}}}{\left(\mathrm{k}_{\text {reaction }}\right)^{\frac{1}{3}}}=\left(\frac{\mathrm{P}_{\mathrm{C} 2 \mathrm{H} 2} \mathrm{P}_{\mathrm{H} 2}}{\mathrm{r}_{\mathrm{C} 2 \mathrm{H} 2}}\right)^{\frac{1}{3}}
$$

\begin{tabular}{|c|c|c|c|}
\hline \multirow{2}{*}{$\begin{array}{c}\begin{array}{c}\text { Reaction } \\
\text { Temperature }\end{array} \\
\left({ }^{\circ} \mathrm{C}\right)\end{array}$} & \multicolumn{2}{|c|}{ Partial pressure (atm) } & \multirow{2}{*}{$\frac{\mathbf{R}_{\mathrm{C} 2 \mathrm{H} 2}}{\text { (mol/gcat. min) }}$} \\
\hline & $\mathrm{P}_{\mathrm{C}} 2 \mathrm{H}^{2}$ & $\mathrm{PH}_{2}$ & \\
\hline \multirow{3}{*}{700} & 0.0928 & 2.1351 & 0.0066 \\
\hline & 0.0846 & 1.9467 & 0.0055 \\
\hline & 0.0888 & 2.043 & 0.0061 \\
\hline \multirow{3}{*}{750} & 0.0742 & 1.7061 & 0.0042 \\
\hline & 0.0762 & 1.7537 & 0.0045 \\
\hline & 0.0789 & 1.8153 & 0.0048 \\
\hline \multirow{3}{*}{800} & 0.1289 & 2.9644 & 0.0128 \\
\hline & 0.1305 & 3.0012 & 0.0131 \\
\hline & 0.1153 & 2.6514 & 0.0102 \\
\hline \multirow{3}{*}{850} & 0.0815 & 1.8748 & 0.0051 \\
\hline & 0.0828 & 1.9039 & 0.0053 \\
\hline & 0.0834 & 1.9183 & 0.0054 \\
\hline \multirow{3}{*}{900} & 0.0322 & 0.7411 & 0.0008 \\
\hline & 0.0699 & 1.6066 & 0.0038 \\
\hline & 0.072 & 1.6571 & 0.004 \\
\hline
\end{tabular}

$$
\begin{aligned}
& \mathrm{k}_{1}=\left(\mathrm{k}_{\text {reaction }}\right)^{\frac{1}{3}} \\
& \mathrm{k}_{2}=\mathrm{k}_{\mathrm{C} 2 \mathrm{H} 2} \\
& \mathrm{k}_{3}=(11)
\end{aligned}
$$

Table 1: Gas-phase concentration of acetylene and hydrogen in the CVD reactor.

The estimation data of kinetics parameters were computed and the results are presented in Table 2 . The activation energy $\mathrm{E}(\mathrm{J} / \mathrm{mol})$ and the frequency factor A (per second) were determine by plotting in $\left(\mathrm{K}_{\text {reaction }}\right)$ against $1 / \mathrm{T}$ base on the Arrhenius equation (13) [29].

$$
\mathrm{k}_{\text {reaction }}=A \mathrm{e}^{-\frac{E}{R T}}
$$

Taking the natural logarithm of both sides in Equation (13), we have Equation (14)

$$
\text { In }\left(\mathrm{k}_{\text {reaction }}\right)=\operatorname{In}(A)-\frac{E}{R}\left(\frac{1}{T}\right)
$$

Where $\mathrm{K}_{\text {reaction }}$ is the reaction rate constant, $\mathrm{R}$ is the gas constant $(8.314 \mathrm{~J} / \mathrm{mol})$ and $\mathrm{T}$ is the absolute temperature $(\mathrm{K})$.

\begin{tabular}{|l|l|l|l|}
\hline $\mathbf{T}\left({ }^{\circ} \mathbf{C}\right)$ & $\mathbf{k}_{\text {reaction }}$ & $\mathbf{K}_{\mathrm{C} 2 \mathrm{H} 2}$ & $\mathbf{K H}_{2}$ \\
\hline 700 & $8.93 \mathrm{E}-05$ & 9.7194241 & 1.455795 \\
\hline 750 & 0.00029213 & 10.263342 & 1.417312 \\
\hline 800 & 0.00181886 & 5.028676 & 0.543685 \\
\hline
\end{tabular}




\begin{tabular}{|l|l|l|l|}
\hline 850 & 0.00815072 & 2.0871586 & 0.158471 \\
\hline 900 & 0.00835337 & 7.6981468 & 0.516337 \\
\hline
\end{tabular}

Table 2: The estimation data of kinetics parameters.

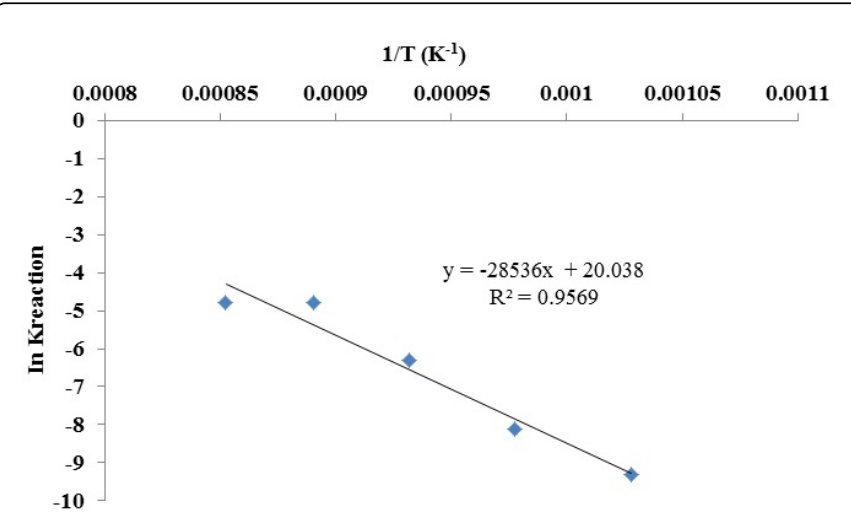

Figure 2: Arrhenius plot for the determination of activation energy (E) and frequency factor $(\mathrm{A})$.

Figure 2 revealed a strong fitting of the Langmuir Hinshelwood equation to the kinetic data with $\mathrm{R}^{2}$ value of 0.9569 . Also, the value of the activation energy was obtained to be $237.2483 \mathrm{~kJ} / \mathrm{mol}$, which implies that the proposed mechanism by adsorption process is correct (i.e. acetylene bonds are broken down for the formation of new molecules of CNTs). In addition, the frequency factor (A) was obtained to be $5.0396 \times 108 / \mathrm{min}$ which showed that the reactant species collide at faster rate for the formation of the CNTs. Substituting the values for $\mathrm{K}_{\text {reaction, }} \mathrm{KC}_{2} \mathrm{H}_{2}$ and $\mathrm{KH}_{2}$ from Table 2 into Equation 7 for the prediction of the rate of decomposition of the acetylene at $700^{\circ} \mathrm{C}$, $750^{\circ} \mathrm{C}, 800^{\circ} \mathrm{C}, 850^{\circ} \mathrm{C}$ and $900^{\circ} \mathrm{C}$. Equations $(15-19)$ are the formulated model from the Langmuir Hinshelwood model for predicting rate of decomposition of the acetylene at different reaction temperature.

Rate of decomposition of the acetylene at $700^{\circ} \mathrm{C}$

$\mathrm{C} 2 \mathrm{H} 2 @ 700^{\circ} \mathrm{C}$

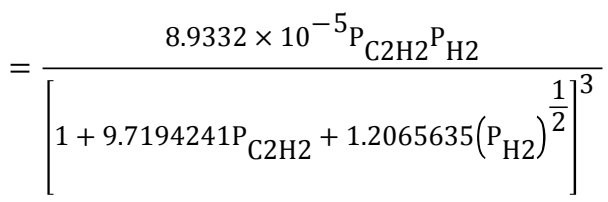

Rate of decomposition of the acetylene at $750^{\circ} \mathrm{C}$

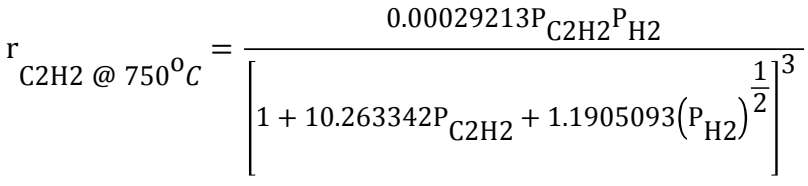

(16)
Rate of decomposition of the acetylene at $800^{\circ} \mathrm{C}$

${ }_{\mathrm{C} 2 \mathrm{H} 2 @ 800^{\circ} C}=\frac{0.00181886 \mathrm{P}_{\mathrm{C} 2 \mathrm{H} 2} \mathrm{P}_{\mathrm{H} 2}}{\left[1+5.028676 \mathrm{P}_{\mathrm{C} 2 \mathrm{H} 2}+0.7373501\left(\mathrm{P}_{\mathrm{H} 2}\right)^{\frac{1}{2}}\right]^{3}}$

Rate of decomposition of the acetylene at $850^{\circ} \mathrm{C}$

$r_{\mathrm{C} 2 \mathrm{H} 2 @ 850^{\circ} \mathrm{C}}=\frac{0.00815072 \mathrm{P}_{\mathrm{C} 2 \mathrm{H} 2} \mathrm{P}_{\mathrm{H} 2}}{\left[1+2.0871586 \mathrm{P}_{\mathrm{C} 2 \mathrm{H} 2}+0.3980838\left(\mathrm{P}_{\mathrm{H} 2}\right)^{\frac{1}{2}}\right]^{3}}$

Rate of decomposition of the acetylene at $900^{\circ} \mathrm{C}$

$\mathrm{r}$ C2H $2 @ 900^{\circ} \mathrm{C}$

$$
=\frac{0.00835337 \mathrm{P}_{\mathrm{C} 2 \mathrm{H} 2} \mathrm{P}_{\mathrm{H} 2}}{\left[1+7.6981468 \mathrm{P}_{\mathrm{C} 2 \mathrm{H} 2}+0.7185662\left(\mathrm{P}_{\mathrm{H} 2}\right)^{\frac{1}{2}}\right]^{3}}
$$

\section{Characterization of the prepared CNTs at different temperature}

The prepared materials collected from the CVD reactor at different reaction temperature $\left(700^{\circ} \mathrm{C}, 750^{\circ} \mathrm{C}, 800^{\circ} \mathrm{C}, 850^{\circ} \mathrm{C}\right.$ and $\left.900^{\circ} \mathrm{C}\right)$ were analyzed using scanning electron microscope (SEM), selected area electron diffraction (SAED) pattern, transmission electron microscope (TEM) and energy dispersive spectroscopy (EDS) in order to confirm that the deposited carbons are CNTs. The SEM images in Figures 3a-7a revealed formation of nanotubes at all the reaction temperatures. The SEM results also indicate decreased in the tubes diameters with increase in temperature from 700 to 900 s and the radial distribution gets narrower at $900^{\circ} \mathrm{C}$ with better structural quality. The variation in structural quality as the temperature increases can be attributed to the fact that, at $700^{\circ} \mathrm{C}$ the catalyst was deactivated before all metal particles (Fe-Ni) were completely reduced therefore, loss of catalytic activity occurred which resulted in an incomplete decomposition of $\mathrm{C}_{2} \mathrm{H}_{2}$ gas, while the better structural quality observed at $900^{\circ} \mathrm{C}$ indicate complete decomposition of the $\mathrm{C}_{2} \mathrm{H}_{2}$ gas.

Furthermore, the SAED patterns in Figures $3 \mathrm{~b}-7 \mathrm{~b}$ exhibits a strong rings with a strong spots for (002), together with a ring for (110) and a pair of weak rings for (111) and (211) diffractions. There are diffuse haloes due to the amorphous carbon film on the copper grid and sharp rings due to the CNT. The reciprocal lattice spacing (1/d) of 3.0, 4.2, 5.2 and $7.2 \mathrm{~nm}^{-1}$ measured from the rings occurrences in Figures $3 \mathrm{~b}-7 \mathrm{~b}$ were used to determine the interplanar distance (d). The 
Citation: Ahmed A, Abdulhakim SA, Ishaq K, Saka AA, Peter MS, Chidinma OU (2017) Carbon Nanotubes: Mechanism, Langmuir Hinshelwood Growth Kinetics and It Application for the Removal of Chromium (VI). J Membr Sci Technol 7: 174. doi:10.4172/2155-9589.1000174

Page 5 of 10

interplanar spacing values are calculated from Bragg's diffraction equation using the diffraction ring diameter and the camera length of the transmission electron microscope (TEM). The calculated results presented in Table 3 indicate the interlayer spacing in the walls, about $0.33 \mathrm{~nm}$, corresponds to (002) distance of graphite carbon which are in good agreement with those in literature for graphite. The SAED patterns in Figures $3 \mathrm{~b}-7 \mathrm{~b}$ for all the samples at various conditions gave very consistent result as expected (i.e. ring distance). This is because, the appearance of (002) plane diffractions as a pair of rings indicates orientation of the (002) planes in the CNTs for all the samples.

More so, the TEM images in Figures 3c-7c revealed the formation of wall structures of CNTs with an encapsulated metal nanoparticles along the inside diameter of the nanotubes samples which resulted from the metal catalyst. The TEM images in Figure $3 \mathrm{c}-7 \mathrm{c}$ also indicate the multiple walls and concentric tubes with diameters less than 100 nm Figures 4-7. Whereas the EDS showed that the carbon contents increased from 84.91 wt.\% to 95.29 wt.\% with increase in temperature from $700^{\circ} \mathrm{C}$ to $900^{\circ} \mathrm{C}$.

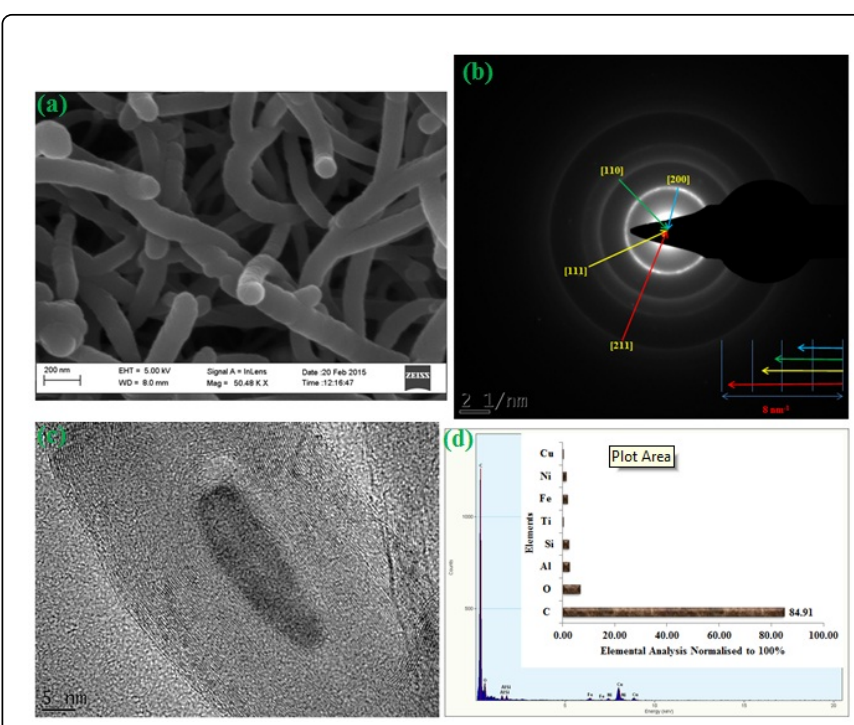

Figure 3: (a) SEM image (b) SAED pattern (c) TEM image (d) EDS of CNTs at $700^{\circ} \mathrm{C}$.

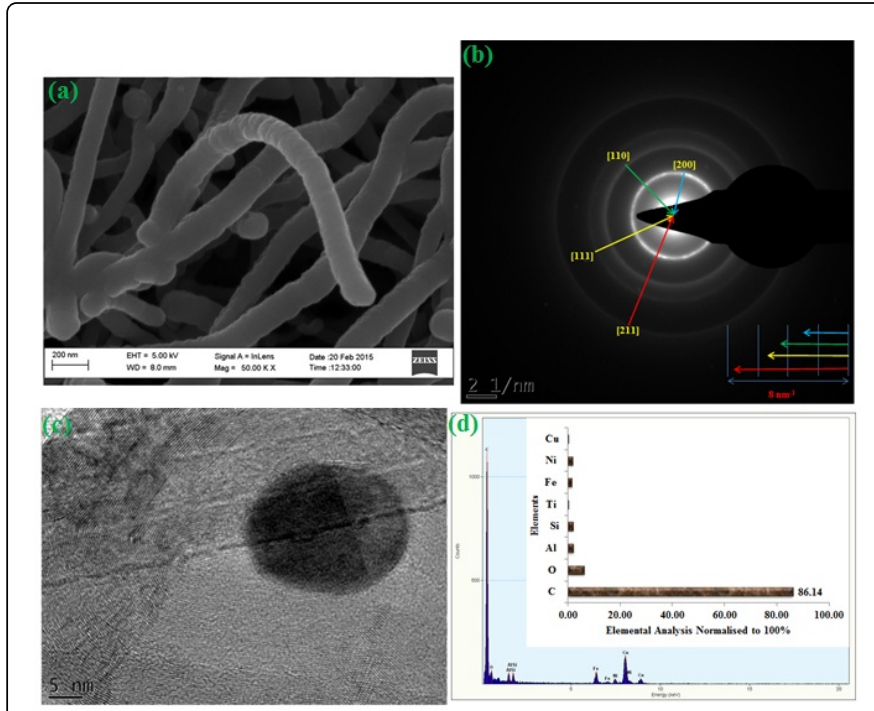

Figure 4: (a) SEM image (b) SAED pattern (c) TEM image (d) EDS of CNTs at $750^{\circ} \mathrm{C}$.

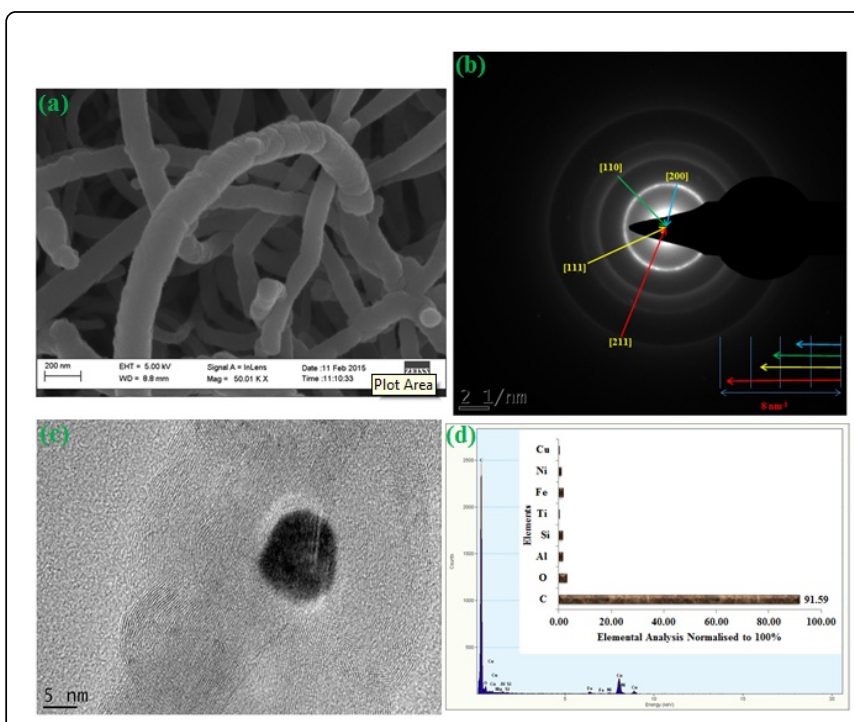

Figure 5: (a) SEM image (b) SAED pattern (c) TEM image (d) EDS of CNTs at $800^{\circ} \mathrm{C}$. 
Page 6 of 10

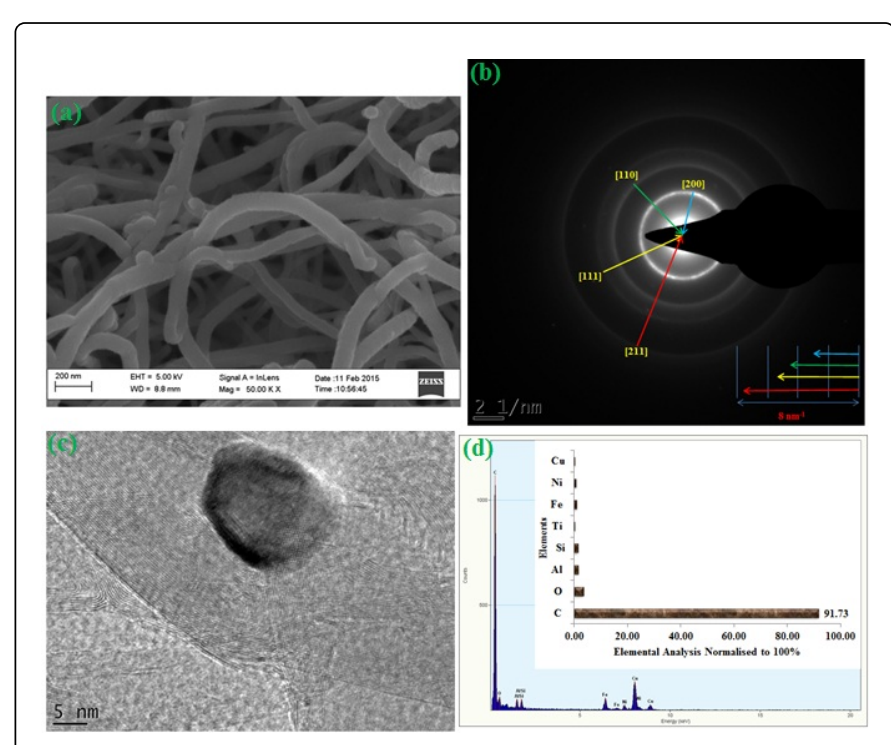

Figure 6: (a) SEM image (b) SAED pattern (c) TEM image (d) EDS of CNTs at $850^{\circ} \mathrm{C}$.

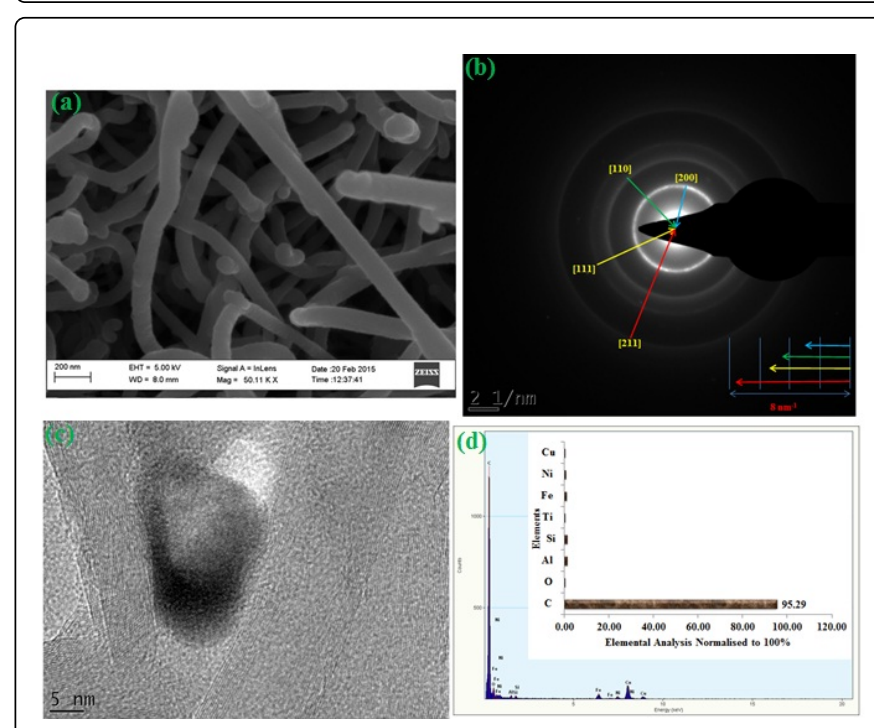

Figure 7: (a) SEM image (b) SAED pattern (c) TEM image (d) EDS of CNTs at $900^{\circ} \mathrm{C}$.

\begin{tabular}{|c|l|l|l|}
\hline \multirow{4}{*}{} & $\mathbf{h}, \mathbf{k}, \mathbf{I}$ & $\mathbf{d}_{\mathrm{hkl}}(\mathbf{n m})$ & $\mathbf{1} / \mathbf{d}_{\mathrm{hkl}}\left(\mathbf{n m}^{-1}\right)$ \\
\cline { 2 - 4 } & $0,0,2^{* *}$ & 0.3333 & 3 \\
\cline { 2 - 4 } & $1,1,0^{*}$ & 0.2381 & 4.2 \\
\cline { 2 - 4 } Graphite & $1,1,1$ & 0.1923 & 5.2 \\
\cline { 2 - 4 } & $2,1,1$ & 0.1389 & 7.2 \\
\hline
\end{tabular}

The first and second most strongly scattering lattice planes are respectively denoted ${ }^{* *}$ and *

Table 3: Strongly scattering lattice planes in graphite.
In addition, the BET surface area was used to characterize the prepared CNTs and the results are presented in Table 4 . Table 4 shows that the prepared CNTs have high surface areas as results of their nanoscale sizes. The BET surface area decreases from $534.45 \mathrm{~m}^{2} / \mathrm{g}$ to $379.44 \mathrm{~m}^{2} / \mathrm{g}$ at a temperature of $700^{\circ} \mathrm{C}$ and $750^{\circ} \mathrm{C}$ respectively. At $800^{\circ} \mathrm{C}$ reaction temperature, CNTs with highest BET surface area of $567.10 \mathrm{~m}^{2} / \mathrm{g}$ was formed. But above $800^{\circ} \mathrm{C}$, the surface area decreases.

\begin{tabular}{|l|l|}
\hline \multicolumn{1}{|c|}{ Reaction Temperature } & \multicolumn{1}{|c|}{ BET Surface Area $\left(\mathbf{m}^{2} / \mathbf{g}\right)$} \\
\hline 700 & 534.45 \\
\hline 750 & 379.44 \\
\hline 800 & 567.1 \\
\hline 850 & 472.98 \\
\hline 900 & 388.05 \\
\hline
\end{tabular}

Table 4: BET surface area of CNTs prepared at different reaction temperature.

It can be observed in Table 4 that CNTs prepared at reaction temperature of $800^{\circ} \mathrm{C}$ gives the highest BET surface area of 567.10 $\mathrm{m}^{2} / \mathrm{g}$ than that of the $\mathrm{CNTs}$ prepared at $700^{\circ} \mathrm{C}, 750^{\circ} \mathrm{C}, 850^{\circ} \mathrm{C}$ and $900^{\circ} \mathrm{C}$. This surface area can be considered well enough for an adsorption process to take place.

\section{Adsorption studies of chromium (VI) ion onto the prepared CNTs at $800^{\circ} \mathrm{C}$}

More previously mention, CNTs prepared at $800^{\circ} \mathrm{C}$ give the highest BET surface area than when compared with others prepared at $700^{\circ} \mathrm{C}$, $750^{\circ} \mathrm{C}, 850^{\circ} \mathrm{C}$ and $900^{\circ} \mathrm{C}$. Therefore, the CNTs at $800^{\circ} \mathrm{C}$ are used as an adsorbent in the adsorption study of chromium (VI) ion.

Effect of CNTs Dosage on the percentage removal of chromium (VI) ion: The resulted presented in Figure 8 show the effect of CNTs dosage on the removal of $\mathrm{Cr}(\mathrm{VI})$ ion at a $\mathrm{pH}$ of 7 in room temperature and contact time of $45 \mathrm{~min}$ with initial $\mathrm{Cr}(\mathrm{VI})$ concentration of $10 \mathrm{mg} / \mathrm{L}$, $50 \mathrm{mg} / \mathrm{L}$ and $100 \mathrm{mg} / \mathrm{L}$. The figure revealed that the removal of $\mathrm{Cr}(\mathrm{VI})$ ion increases from $89.8 \%$ to $99.3,88.5 \%$ to $97.15 \%$ and $87.0 \%$ to 96.9 $\%$ for the initial Cr (VI) ion concentration of $10 \mathrm{mg} / \mathrm{L}, 50 \mathrm{mg} / \mathrm{L}$ and $100 \mathrm{mg} / \mathrm{L}$ respectively as the adsorbent dosage increases. It is observed that after $0.8 \mathrm{~g}$ of mass of the CNTs adsorbent, there is no significant change in the percentage removal of $\mathrm{Cr}(\mathrm{VI})$ and this may be due to the overlapping of active sites at high CNTs dosage which reduces the effective surface area because of the conglomeration of the particles exchange. Therefore, $0.8 \mathrm{~g} / 100 \mathrm{~mL}$ is considered as the optimum CNTs dosage which is used for further studies. 


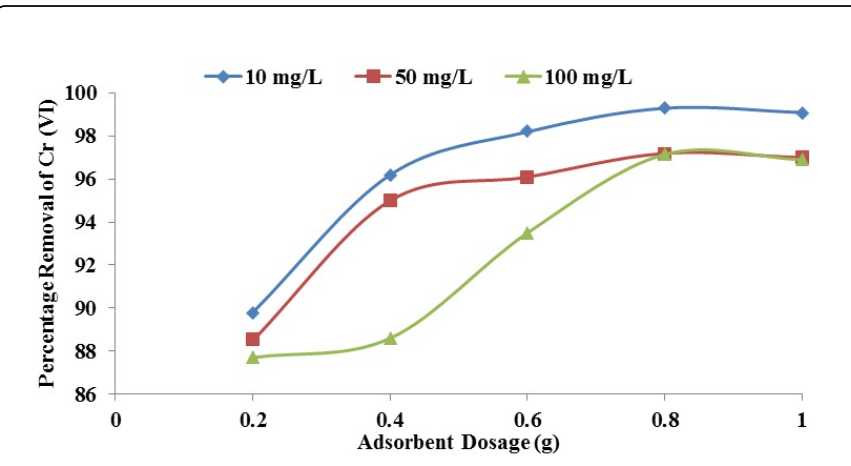

Figure 8: Effect of CNTs Dosage on the percentage removal of chromium (VI) ion.

Effect of $\mathrm{pH}$ on the percentage removal of chromium (VI) ion: The results in Figure 9 show the effect of $\mathrm{pH}$ on percentage removal of $\mathrm{Cr}$ (VI) at different $\mathrm{pH}$ using $0.8 \mathrm{~g}$ of CNTs in chromium solution by keeping other parameters constant. These results revealed that, there is an increase in percentage removal of $\mathrm{Cr}(\mathrm{VI})$ with increase in $\mathrm{pH}$ until 8. After a $\mathrm{pH}$ of 8 , it was observed that the percentage removal of the ions started to decrease and this confirmed that $\mathrm{Cr}(\mathrm{VI})$ ion removal is favorable at alkalinity medium. Similar results are reported in chromium removal by aluminum magnesium mixed with hydroxide [30].

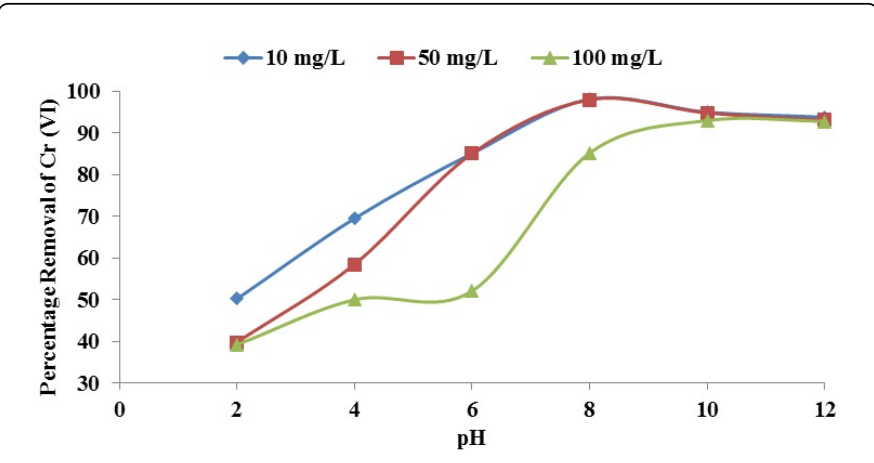

Figure 9: Effect of $\mathrm{pH}$ on the percentage removal of chromium (VI) ion.

Effect of contact time on the percentage removal of chromium (VI) ion: The results of the effect of contact time on the percentage removal of $\mathrm{Cr}$ (VI) for initial concentration of $10 \mathrm{mg} / \mathrm{L}, 50 \mathrm{mg} / \mathrm{L}$ and $100 \mathrm{mg} / \mathrm{L}$ at optimum CNTs dosage and $\mathrm{pH}$ of 7 is presented in Figure 10. It cleared from the figure that equilibrium is reached after $45 \mathrm{~min}$ for initial $\mathrm{Cr}$ (VI) ion concentration of $10 \mathrm{mg} / \mathrm{L}$ and $60 \mathrm{~min}$ for initial $\mathrm{Cr}$ (VI) concentration of $50 \mathrm{mg} / \mathrm{L}$ and $100 \mathrm{mg} / \mathrm{L}$. This observable trend may be due to the fact that the total vacant sites in the prepared CNTs initially and the solute concentration gradient were very high. As the time increases, the $\mathrm{Cr}(\mathrm{VI})$ ion uptake rate by the CNTs decreases due to decrease in the number of active adsorption sites as well as $\mathrm{Cr}$ (VI) ion concentration. Similar results have been reported by many researchers.

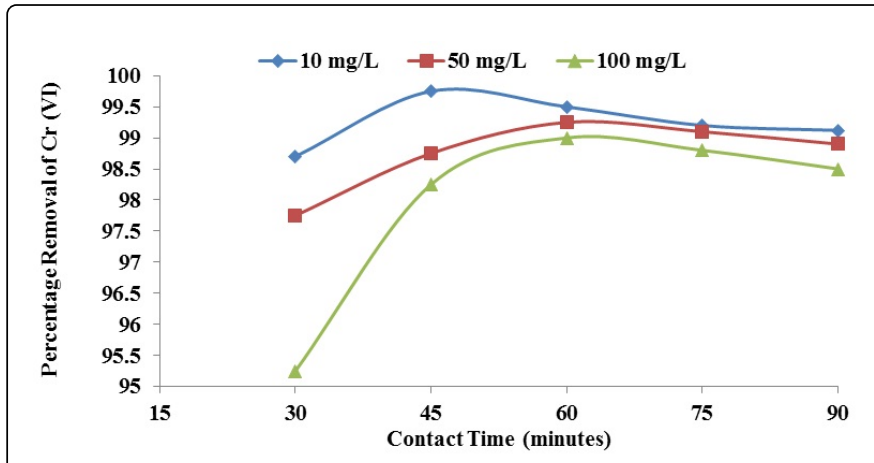

Figure 10: Effect of contact time on the percentage removal of chromium (VI) ion.

Effect of temperature on the percentage removal of chromium (VI) ion: The results of the effect of temperature on the percentage removal of $\mathrm{Cr}$ (VI) ion for initial concentration of $10 \mathrm{mg} / \mathrm{L}, 50 \mathrm{mg} / \mathrm{L}$ and 100 $\mathrm{mg} / \mathrm{L}$ at optimum CNTs dosage and $\mathrm{pH}$ of 7 is presented in Figure 11. The figure revealed that increase in temperature from $30^{\circ} \mathrm{C}$ to $45^{\circ} \mathrm{C}$ increases the percentage removal of Cr (VI) ion from $94 \%$ to $99.51 \%$, $95 \%$ to $99.3 \%$ and $98.2 \%$ to $99.3 \%$ for initial Cr (VI) ion concentration of $10 \mathrm{mg} / \mathrm{L}, 50 \mathrm{mg} / \mathrm{L}$ and $100 \mathrm{mg} / \mathrm{L}$ respectively which shows the endothermic nature of the adsorption process and this may be probably due to the decrease in the escaping tendency of the adsorbate species from the surface of the CNTs adsorbent. Similar findings have been reported by Rengaraj et al. [31], which study the removal of chromium in wastewater using ion exchange resins.

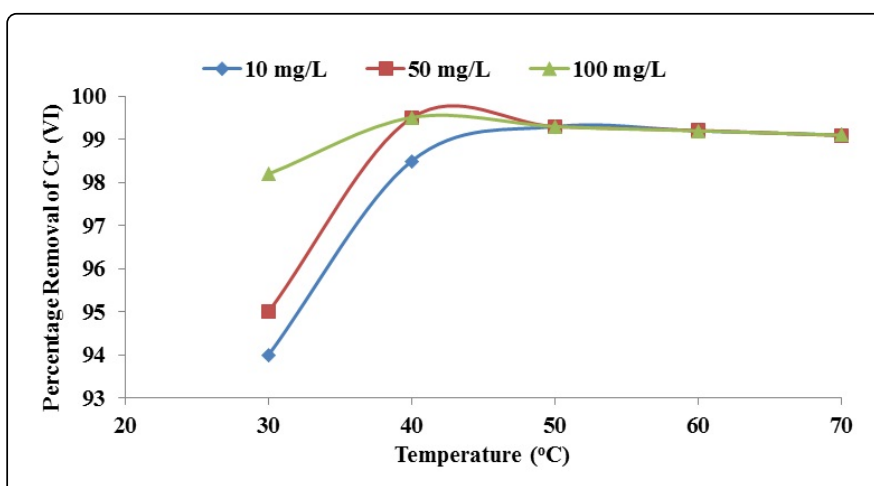

Figure 11: Effect of temperature on the percentage removal of chromium (VI) ion.

\section{Kinetic studies of chromium (VI) ion onto the prepared CNTs at $800^{\circ} \mathrm{C}$}

In order to understand the efficiency of the adsorption process of the chromium (VI) ion onto the prepared CNTs, the pseudo first order (Lagergren rate equation) and second order rate equations are applied to model the kinetic of $\mathrm{Cr}(\mathrm{VI})$ ion adsorption onto the CNTs. Figure 12 shows a straight lines plots of $\log \left(\mathrm{q}_{\mathrm{e}}-\mathrm{q}_{\mathrm{t}}\right)$ against time $(\mathrm{t})$ for initial $\mathrm{Cr}(\mathrm{VI})$ ion concentration of $10 \mathrm{mg} / \mathrm{L}, 50 \mathrm{mg} / \mathrm{L}$ and $100 \mathrm{mg} / \mathrm{L}$ while the plots of linearized second order rate equation for initial Cr (VI) ion concentration of $10 \mathrm{mg} / \mathrm{L}, 50 \mathrm{mg} / \mathrm{L}$ and $100 \mathrm{mg} / \mathrm{L}$ were shown in Figure 13. 
Citation: Ahmed A, Abdulhakim SA, Ishaq K, Saka AA, Peter MS, Chidinma OU (2017) Carbon Nanotubes: Mechanism, Langmuir Hinshelwood Growth Kinetics and It Application for the Removal of Chromium (VI). J Membr Sci Technol 7: 174. doi:10.4172/2155-9589.1000174

Page 8 of 10

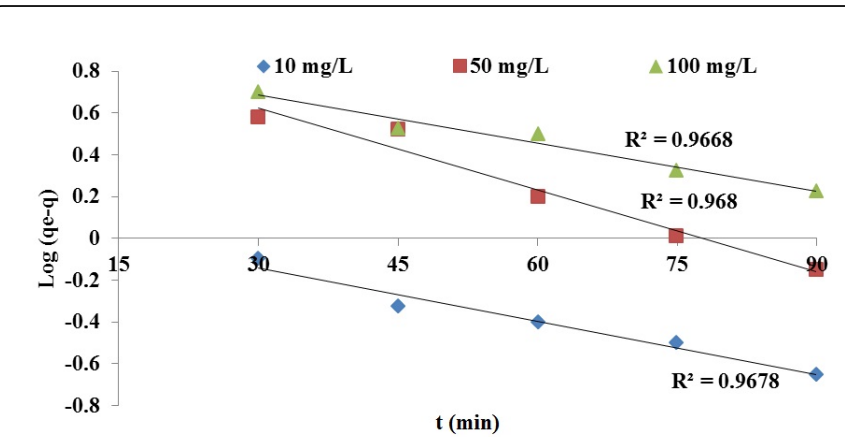

Figure 12: Pseudo first order reaction of chromium (VI) ion adsorbed onto CNTs.

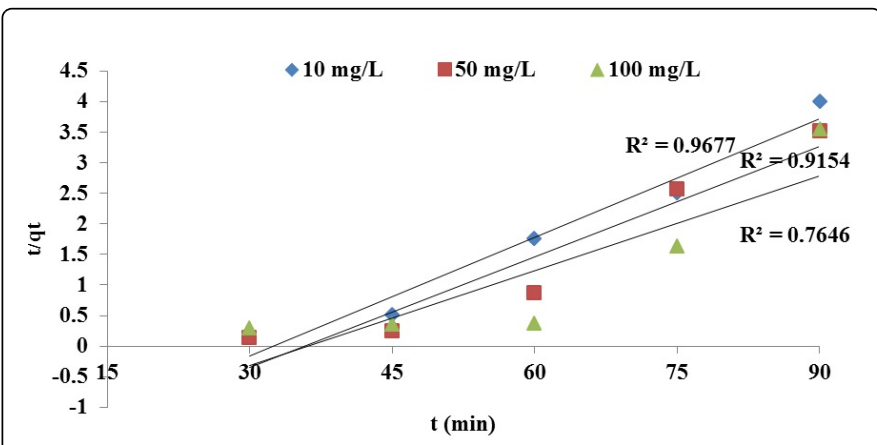

Figure 13: Pseudo second order reaction of chromium (VI) ion adsorbed onto CNTs.

The pseudo first and second order rate equation constants from Figures 12 and 13 for initial Cr (VI) ion concentration of $10 \mathrm{mg} / \mathrm{L}, 50$ $\mathrm{mg} / \mathrm{L}$ and $100 \mathrm{mg} / \mathrm{L}$ were determined and the results are presented in Table 5 along with the corresponding correlation coefficients. Table 5 reveal that the coefficient of determination $\left(R^{2}\right)$ for second order rate equation is less than that of first order rate equation, which suggested that the adsorption process in this experimental study followed the first order Lagergren's kinetic.

\begin{tabular}{|c|c|c|c|c|c|c|}
\hline \multirow{2}{*}{$\begin{array}{c}\begin{array}{c}\text { Initial } \mathrm{Cr} \\
\text { (VI) ion } \\
\text { Conc. }\end{array} \\
\text { (mg/L) }\end{array}$} & \multicolumn{3}{|c|}{$\begin{array}{c}\text { Pseudo First Order Rate } \\
\text { Equation }\end{array}$} & \multicolumn{3}{|c|}{ Second Order Rate Equation } \\
\hline & $\mathrm{K}_{1}$ & $q_{e}$ & \multirow{2}{*}{$\mathrm{R}^{2}$} & $\mathrm{~K}_{2}$ & $q_{e}$ & \multirow{2}{*}{$\mathrm{R}^{2}$} \\
\hline & $\left(\mathrm{min}^{-1}\right)$ & $(\mathrm{mg} / \mathrm{g})$ & & $\underset{\left.m g^{-1} \mathrm{~min}^{-1}\right)}{(\mathrm{g}}$ & $(\mathrm{mg} / \mathrm{g})$ & \\
\hline 10 & 0.0196 & 1.1223 & 0.9877 & 0.002 & $\begin{array}{c}15.408 \\
3\end{array}$ & 0.9677 \\
\hline 50 & 0.0302 & 2.7585 & 0.9826 & 0.0017 & $\begin{array}{c}16.583 \\
7\end{array}$ & 0.9154 \\
\hline 100 & 0.0177 & 2.4973 & 0.8925 & 0.0014 & $\begin{array}{c}19.342 \\
4\end{array}$ & 0.7646 \\
\hline
\end{tabular}

Table 5: Pseudo first and second order rate equations constants.

\section{Isotherm studies of chromium (VI) ion onto the prepared CNTs at $800^{\circ} \mathrm{C}$}

The linear plots of the Langmuir, Freundlich, DubininRadushkevich and Temkin isotherm models for the adsorption of $\mathrm{Cr}$ (VI) ion onto the prepared CNTs are presented in Figures 14-17 respectively. The straight lines plots of the isotherms confirmed the satisfactory fits of the application of the Langmuir, Freundlich, Dubinin-Radushkevich and Temkin isotherm models to the adsorption of $\mathrm{Cr}(\mathrm{VI})$ ion onto the CNTs adsorbent.

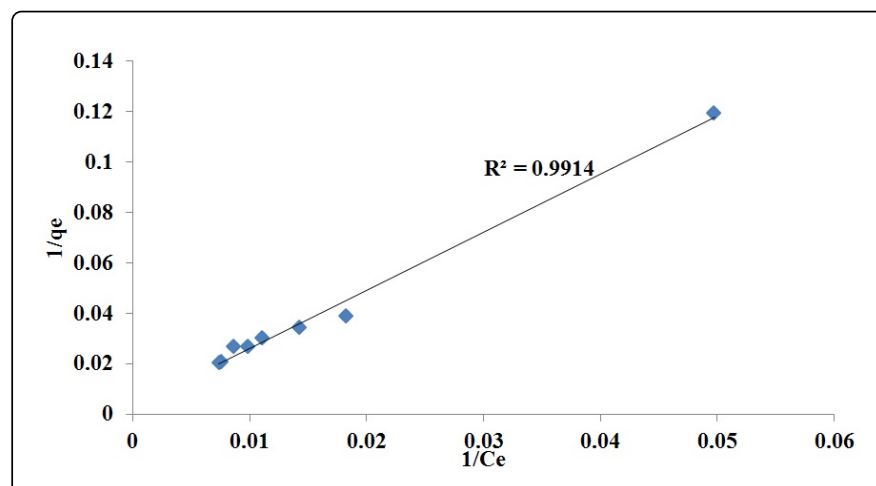

Figure 14: Langmuir Adsorption Isotherms.

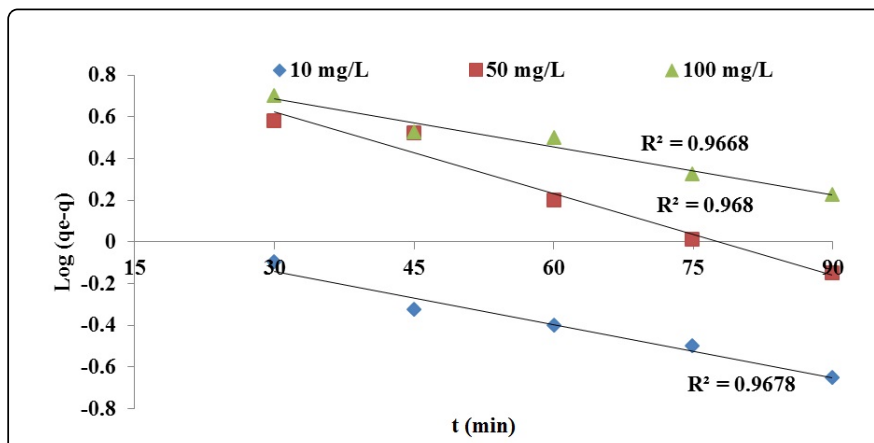

Figure 15: Freundlich Adsorption Isotherms.

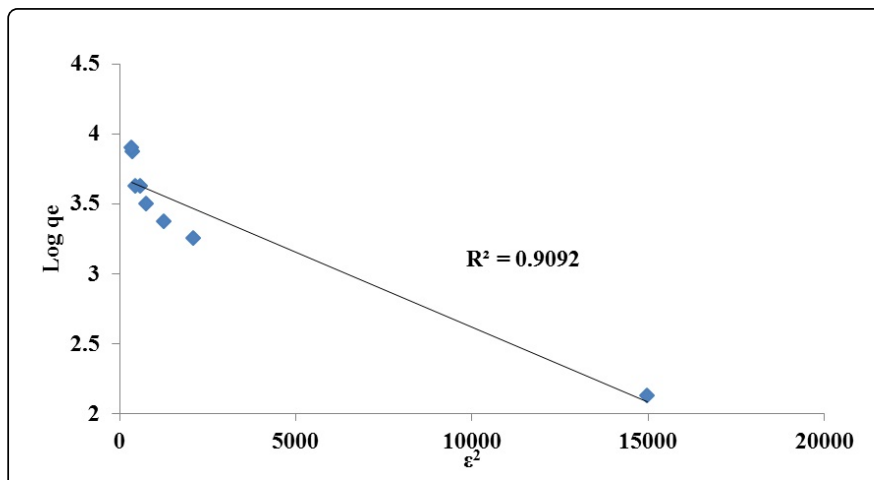

Figure 16: Dubinin-Radushkevich Adsorption Isotherms. 


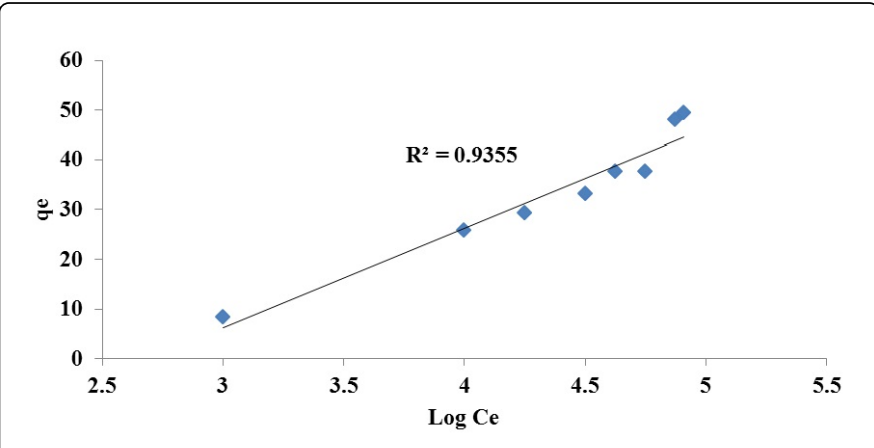

Figure 17: Temkin Adsorption isotherms.

Base on the graphical representation of the Langmuir, Freundlich, Dubinin-Radushkevich and Temkin isotherm models in the above figures, the isotherms constants values were computed and the results were presented in Table 6.

\begin{tabular}{|c|c|c|}
\hline \multicolumn{3}{|c|}{ Langmuir isotherm constant } \\
\hline $\mathrm{K}_{\mathrm{L}}(\mathrm{L} / \mathrm{mg})$ & $\mathrm{Q}_{\mathrm{O}}(\mathrm{mg} / \mathrm{g})$ & $\mathrm{R}^{2}$ \\
\hline 0.001301 & 333.3333 & 0.9914 \\
\hline \multicolumn{3}{|c|}{ Freundlich isotherm constant } \\
\hline $\mathrm{K}_{\mathrm{f}}\left(\mathrm{mg}^{-1}\right)$ & $\mathrm{n}$ & $\mathrm{R}^{2}$ \\
\hline 0.642493 & 1.133016 & 0.9758 \\
\hline \multicolumn{3}{|c|}{ Dubinin-Radushkevich isotherm constant } \\
\hline $\mathrm{K}$ & $\mathrm{q}_{\mathrm{m}}(\mathrm{g} / \mathrm{g})$ & $\mathrm{R}^{2}$ \\
\hline 0.0001 & 40.0088 & 0.9092 \\
\hline \multicolumn{3}{|c|}{ Temkin isotherm constant } \\
\hline $\mathrm{A}_{\mathrm{T}}(\mathrm{L} / \mathrm{g})$ & $\beta$ & $\mathrm{R}^{2}$ \\
\hline 0.06784 & 20.105 & 0.9355 \\
\hline
\end{tabular}

Table 6: Summary of values for isotherms models of chromium (VI) ion onto CNTs.

From Table 6, the $\mathrm{R}^{2}$ value obtained for the Langmuir isotherm was 0.9914 indicating the applicability of the Langmuir adsorption isotherm, and the values of $\mathrm{Q}_{\mathrm{O}}$ and $\mathrm{K}_{\mathrm{L}}$ were calculated to be 333.33 $\mathrm{mg} / \mathrm{g}$ and $0.0013 \mathrm{~L} / \mathrm{mg}$ respectively. Meanwhile, for the Freundlich isotherm, the $\mathrm{R}^{2}$ value obtained was $0.9758, \mathrm{~K}_{\mathrm{F}}$ and $\mathrm{n}$ were evaluated to be 0.6425 and 1.133 respectively. Also, the Dubinin Radushkevich $\mathrm{R}^{2}$ was found to be 0.9092 and the values of $K$ and $q_{m}$ were calculated to be 0.0001 and 40.0088 respectively, while the $R^{2}, A_{T}$ and $\beta$ were calculated to be $0.9355,0.06784 \mathrm{~L} / \mathrm{g}$ and 20.105 respectively for the Temkin isotherm. It is clear that the Langmuir isotherm fits better than Freundlich, Dubinin Radushkevich and Temkin isotherm on the basis of correlation coefficient values and this implies that the Langmuir model is more appropriate to describe the adsorption characteristic of $\mathrm{Cr}$ (VI) ions onto CNTs adsorbent in this study.

The Langmuir, Freundlich, Dubinin Radushkevich and Temkin equations were developed to fit $\mathrm{Cr}$ (VI) ions equilibrium adsorption capacity, $\mathrm{q}_{\mathrm{e}}$ onto the CNTs adsorbent. The Equations (20-23) represent the developed Langmuir, Freundlich, Dubinin Radushkevich and Temkin equations for adsorption of $\mathrm{Cr}$ (VI) ions onto the CNTs adsorbent.

The developed Langmuir Equation;

$\frac{1}{q_{e}}=\frac{2.3063}{C_{e}}+0.003$

The developed Freundlich Equation;

$q_{e}=0.642493 C_{e}^{0.8826}$

The developed Dubinin Radushkevich Equation;

$q_{e}=40.008823 \exp \left(-0.0001 \varepsilon^{2}\right)$

The developed Temkin Equation;

$q_{e}=20.105 \log \left(0.06784 C_{e}\right)$

\section{Conclusions}

In summary, CNTs was successfully synthesized using bimetallic catalyst (Fe-Ni) supported on kaolin via CVD method by measuring the activation and frequency factor of acetylene $\left(\mathrm{C}_{2} \mathrm{H}_{2}\right)$ decomposition. The kinetic studies showed that the CVD reaction is controlled and described by the Langmuir Hinshelwood kinetic model. This study demonstrated the mechanism and growth kinetics of CNTs by CVD method using acetylene gas as carbon source and $\mathrm{F}_{\mathrm{e}}-\mathrm{N}_{\mathrm{i}}$ catalyst over kaolin substrate in an inert environment. CNTs synthesized at $800^{\circ} \mathrm{C}$ was observed to be the most highly quality nanotubes containing fewer defects and it was used for adsorption study. The adsorption experiments revealed good capability of the prepared CNTs in removal of chromium (VI) ion at an optimum dosage of $0.8 \mathrm{~g} / 100 \mathrm{~mL}, \mathrm{pH}$ of 8; 45 minutes contact time and temperature of $45^{\circ} \mathrm{C}$. The kinetic adsorption parameters showed that the overall adsorption can be better described by the pseudo first order kinetic model, while the equilibrium data were best fitted by the Langmuir isotherm in the adsorption of $\mathrm{Cr}$ (VI) ion onto the prepared CNTs.

\section{References}

1. Kariim I, Abdulkareem AS, Abubakre OK, Aliyu A, Garba MU, et al. (2015) Optimization of lead (II) ions adsorption on to chemically activated carbon from sugarcane bagasse. Nigeria J Technol Research 10: 27-33.

2. Krawczyk M, Jeszka-Skowron M (2016) Multiwalled carbon nanotubes as solid sorbent in dispersive micro solid-phase extraction for the sequential determination of cadmium and lead in water samples. Microchemical Journal 126: 296-301.

3. Wang F, Lu X, Lia X (2016) Selective removals of heavy metals (Pb2+, $\mathrm{Cu} 2+$ and $\mathrm{Cd} 2+$ ) from wastewater by gelation with alginate for effective metal recovery. J Hazard Mater 308: 75-83.

4. Stafiej A, Pyrzynska K (2007) Adsorption of heavy metal ions with carbon nanotubes. Sep Purif Technol 58: 49-52.

5. Goyer RA (1996) Toxic effects of metals. In Casarett and Doull's toxicology: The basic science of poisons". Toxicology 44: 121-122.

6. Tahir SS, Naseem R (2007) Removal of Cr (III) from tannery wastewater by adsorption onto bentonite clay. Sep Purif Technol 53: 312-321.

7. Sacmac S, Kartal S, Yilmaz Y, Sacmac M, Soykan C (2012) A new chelating resin: Synthesis, characterization and application for speciation of chromium (III)/(VI) species. Chemical Engineering J 181-182: 746-753. 
Citation: Ahmed A, Abdulhakim SA, Ishaq K, Saka AA, Peter MS, Chidinma OU (2017) Carbon Nanotubes: Mechanism, Langmuir Hinshelwood Growth Kinetics and It Application for the Removal of Chromium (VI). J Membr Sci Technol 7: 174. doi:10.4172/2155-9589.1000174

Page 10 of 10

8. Ashraf MM, Hala AMA (2010) Ultrastructure changes in hepatocytes of catfish clarias geriepinus from lake Mariut, Egypt. J Environ Biol 31: 715-720.

9. Jiahua Z, Suying W, Minjiao C, Hongbo G, Sowjanya BR, et al. (2013) Magnetic nanocomposites for environmental remediation. Advanced Powder Technology 24: 459-467.

10. Jung C, Heo J, Han J, Her N, Lee SJ, et al. (2013) Hexavalent chromium removal by various adsorbents: Powdered activated carbon, chitosan, and single/multi-walled carbon nanotubes. Sep Purif Technol 106: 63-71.

11. Panayotova M (2001) Kinetics and thermodynamics of copper ions removal from wastewater by use of zeolite. Waste Manag 21: 671-676.

12. Turker AR (2007) New sorbents for solid-phase extraction for metal enrichment. Clean 35: 548-557.

13. Iijima S (1991) Helical microtubules of graphitic carbon. Nature 354: 56-58.

14. Gamaly EG, Ebbesen TW (1995) Mechanism of carbon nanotube formation in the arc discharge. Phys Rev B 52: 2083-2089.

15. Height MJ, Howard JB, Tester JW, Vander Sande JB (2004) Flame synthesis of single-walled carbon nanotubes. Carbon 42: 2295-2307.

16. Yuan L, Saito K, Pan C, Williams FA, Gordon AS (2001) Nanotubes from methane flames. Chem Phys Lett 340: 237-241.

17. Aliyu A, Abdulkareem AS, Kovo AS, Abubakre OK, Tijani JO, Kariim I (2017) Synthesize multi-walled carbon nanotubes via catalytic chemical vapour deposition method on Fe-Ni bimetallic catalyst supported on kaolin. Carbon Lett 21: 33-50.

18. Mohammed IA, Bankole MT, Abdulkareem AS, Ochigbo SS, Afolabi AS, et al. (2017) Full Factorial Design Approach to Carbon nanotubes synthesis by CVD method in Argon environment. South African Journal of Chemical Engineering 24: 17-42.

19. Voelskow K, Becker MJ, Xia W, Muhler M, Turek T (2014) The influence of kinetics, mass transfer and catalyst deactivation on the growth rate of multiwalled carbon nanotubes from ethane on a cobalt-based catalyst. Chemical Engineering Journal 244: 68-74.

20. Yang X, Zou T, Shi C, Lie E, He C, et al. (2016) Effect of carbon nanotube (CNT) content on the properties of in-situ synthesis CNT reinforced $\mathrm{Al}$ composites. Materials Science and Engineering 660: 11-18.
21. Andrews R, Jacques D, Rao AM, Derbyshire F, Qian D, et al. (1999) Continuous production of aligned carbon nanotubes: a step closer to commercial realization. Chem Phys Lett 303: 467-474 (1999).

22. Aliyu A, Kariim I, Abdulkareem AS (2017) Effects of aspect ratio of Multi-walled carbon nanotubes on coal washery waste water treatment. J Environ Manage 202: 84-93.

23. Abdulrahaman MA, Abubakre OK, Abdulkareem SA, Tijani JO, Aliyu A Afolabi AS (2017) Effect of coating mid steel with CNTs on its mechanical properties and corrosion behaviour in acidic medium. Adv Nat Sci Nanosci Nanotechnol 8: 015016.

24. Kim H, Saiz E, Chhowalla M, Mattevi C (2013) Modeling of the selflimited growth in catalytic chemical vapor deposition of graphene. New Journal of Physics 15: 053012.

25. McCarty KF, Feibelman PJ, Loginova E, Bartelt NC (2009) Kinetics and thermodynamics of carbon segregation and graphene growth on $\mathrm{Ru}$ (0001). Carbon 47: 1806-1813.

26. Losurdo M, Giangregorio MM, Capezzuto P, Bruno G (2011) Graphene CVD growth on copper and nickel: role of hydrogen in kinetics and structure. Physical Chemistry Chemical Physics 13: 20836-20843.

27. Bi H, Sun S, Huang F, Xie X, Jiang M (2012) Direct growth of few-layer graphene films on $\mathrm{SiO} 2$ substrates and their photovoltaic applications. Journal of Materials Chemistry 22: 411-416.

28. Fogler HS (2010) Essentials of Chemical Reaction Engineering. Pearson Education 7.

29. Wang W, Kunwar S, Huang, JY, Wang, DZ, Ren ZF (2005) Low temperature solvothermal synthesis of multiwall carbon nanotubes. Nanotechnology 16: 21-23.

30. Li QL, Zhang X, Yan Y (2009) Kinetic parameters and mechanisms of the batch biosorption of Cr (VI) and Cr (III) onto Leesia hexandra Swartz biomass. J colloid interface Sci 333: 71-77.

31. Rengaraj S, Yeon KH, Moon SH (2001) Removal of chromium from water and wastewater by ion exchange resins. J Hazardous Mater 87: 273-287. 